\title{
Changes in market functioning and central bank policy: an overview of the issues
}

\author{
Marvin J Barth III, Eli M Remolona and Philip D Wooldridge, ${ }^{1}$ \\ Bank for International Settlements
}

\section{Introduction}

In recent years, financial markets have experienced a number of developments that have had a major impact on the way they function. The launch of the euro, the introduction of electronic trading platforms, shifts in the constellation and behaviour of market participants, and changes in relative supplies of different assets have all had a significant influence on the structure and quality of financial markets. Changes in market functioning have in turn posed challenges for central banks' policies, ranging from strategic to operational.

This paper provides an overview of how the functioning of financial markets in industrial countries has changed in recent years and analyses some of the implications of these changes. The focus is primarily on issues of concern to central banks. Its main objective is to provide an overall framework in which the specific contributions to this volume can be more easily located. In the process, it also brings together recent work carried out at the BIS bearing on the questions at hand.

The paper is structured as follows. Section 2 briefly defines market functioning, identifies the issues addressed and explains their interrelationships. Section 3 describes the main forces for change in market functioning during the last few years. Section 4 focuses on shifts in market liquidity. While central banks have always had an interest in market liquidity, the issue has become much more prominent in recent years. In particular, this section seeks to understand how recent structural developments have influenced the liquidity of different market segments, in tranquil as well as stressful conditions. Section 5 considers how structural developments may have affected pricing relationships. The focus here is on the implications for the relationship between the pricing of different instruments and the information contained in these prices. Issues addressed include what pricing relationships can tell us about the degree of integration in the euro markets, the changing information content of default-free yield curves and the pricing of credit risk. The evolving significance of liquidity premia is one of the aspects highlighted. Section 6 then turns to selected implications of these changes for central bank policy. It traces some of the implications for central bank policies on market liquidity, for the transmission mechanism, for the ability of central banks to use the information contained in asset prices as a guide to policy, and for the strategy and tactics of their domestic and foreign currency operations.

\section{Market functioning: the basic concepts}

As used in this paper, market functioning refers to the processes through which financial markets provide liquidity and form prices. While "market microstructure", as defined in the academic literature, focuses on the mechanics of price formation, including how prices are set to reflect new information, functioning is about the effectiveness and reliability of those mechanics. ${ }^{2}$ Hence, a well functioning

1 Thanks are due to Claudio Borio for helpful comments and Anna Cobau for expert statistical assistance. The views expressed in this paper are those of the authors and do not necessarily reflect the views of the BIS.

2 This definition of market microstructure is from Dufour and Engle (2000). They further point out that the literature focuses on the problem of how market-makers learn, from observing trading activity, the information held by informed traders. A key question is to understand the price setting problem faced by intermediaries in a situation where some traders may have superior information. See also O'Hara (2001). O'Hara (1995), Madhavan (2000) and Lyons (2001) survey the literature in this area. 
market may be said to be one that provides robust liquidity and in which prices serve as informative signals about fundamentals. Whether a market functions well in turn depends on how its microstructure adjusts to such things as changes in asset supplies, shifts in the constellation and behaviour of market participants, and new channels of information.

The distinction between fundamentals and liquidity is important. In general, fundamentals can be defined as the factors that are relevant to investment decisions but are exogenous to the market's microstructure. In the case of government bond markets, for instance, fundamentals would include expectations about macroeconomic developments. In the case of equity markets, the fundamentals would involve the prospective earnings of individual companies. The risk attitudes of investors are part of fundamentals too. By contrast, liquidity, loosely defined as the ability to execute transactions at short notice, low cost and with little impact on price, depends on the market's microstructure. A well functioning market would be characterised by maximal and stable liquidity. In such a market, prices would not be driven by shifts in liquidity and would entirely reflect fundamentals. ${ }^{3}$

Of course, this characterisation of a well functioning market is just an ideal benchmark. Liquidity services are highly valued and costly to produce. And the costs of producing them vary across market segments and over time with changing conditions. Prices, therefore, will generally incorporate a significant liquidity component. As discussed further below, in recent years that component has received increasing attention from market participants and central banks alike.

How can we tell if a market is liquid? Harris (1990) proposes four operational criteria to measure liquidity. ${ }^{4}$ Width: is the price wedge between buyers and sellers (or bid-ask spread) narrow? Depth: are large trades executed routinely without price changes? Immediacy: are large trades executed promptly without price changes? Resilience: if prices move due to an order imbalance, do these prices return quickly to normal? Some of these criteria are relatively straightforward to measure, such as width. Others, probably the more important, are much harder to identify, notably depth. Moreover, once liquidity is allowed to vary over time, there is no assurance that markets that are liquid in tranquil conditions will retain liquidity under stress. In fact, some of the factors that increase liquidity in tranquil conditions may actually make it more vulnerable under stress and even sow the seeds of that distress (see below). This makes it all the more important to identify what factors actually promote robust liquidity. For, ultimately, it is robustness that market participants and policymakers care about.

Against this background the following sections explore the factors that influence market functioning and their manifestation in liquidity patterns and pricing. This is an area where our understanding is rather limited and continuously revised in the light of experience. For instance, not long ago the conventional wisdom was that relative supplies would have little impact on relative prices. The evidence in recent years has challenged that prevailing view with a vengeance. Likewise, most of the academic literature on the determinants of liquidity focuses on the implications of asymmetric information about the underlying value of the asset transacted. By contrast, in the next few pages risk management practices of financial institutions play a much more important role.

\section{Developments driving changes in market functioning}

Financial markets are continuously being reshaped by various forces. The period since the late 1990s has been no exception. It has witnessed a number of developments which have already had a major impact on the structure and operation of markets but whose full potential is still unclear. The most important of these developments have been the introduction of the euro, the growth of electronic trading, shifts in the constellation and behaviour of market participants, and changes in the supply of

3 According to the above definition, a well functioning market is characterised with no reference to the accuracy of the market expectations reflected in prices. In other words, the definition says nothing about whether prices converge to their true, full information values or whether they support an efficient allocation of resources and risk. Issues of "informational efficiency" and "market efficiency" are not addressed in this paper. Strictly speaking, expectations, too, could depend on microstructure. In that case, one could think of fundamentals as the expectations that would result in a frictionless market, ie one where liquidity was maximal.

4 Muranaga and Shimizu (1999) adopt these four measures as their definition of liquidity. See also CGFS (1999a). 
instruments. Foreign exchange markets, fixed income markets and markets in Europe have arguably been the most visibly affected. But no market has been left untouched.

\section{The introduction of the euro}

The replacement of 11 European currencies with a single currency in January 1999 had a profound impact on financial markets in the euro area, especially fixed income markets. The integration of securities markets across the euro area had begun well before the launch of the single currency, but the actual introduction of the euro greatly accelerated the process. Integrated bond and money markets emerged within a few weeks of the launch of the euro, aided by the creation of pan-European trading platforms and the harmonisation of market conventions (ECB (2001b)). Equity and repo markets were slower to break out of the segmentation that had characterised them prior to monetary union, held back by remaining differences in tax and legal systems and the absence of a common settlement system (ECB (2001a, c)). In foreign exchange markets, the euro quickly took on the role played by its predecessor currencies (Galati and Tsatsaronis (2001)).

Monetary union led many investors to adopt a euro area-wide perspective in place of a national one when deciding their portfolio allocations. Such a broadening of the investor base for euro-denominated securities enhanced the attractiveness of market-based methods of financing. This is evident from the doubling of the net issuance of debt securities by banks, corporations and other non-government borrowers in the two years following monetary union, to 9\% of GDP (Graph 1). The diversity of instruments and issuers active in euro securities markets also increased appreciably over this period.

\section{Graph 1}

\section{Net issuance of debt securities ${ }^{1}$}

As a percentage of nominal GDP

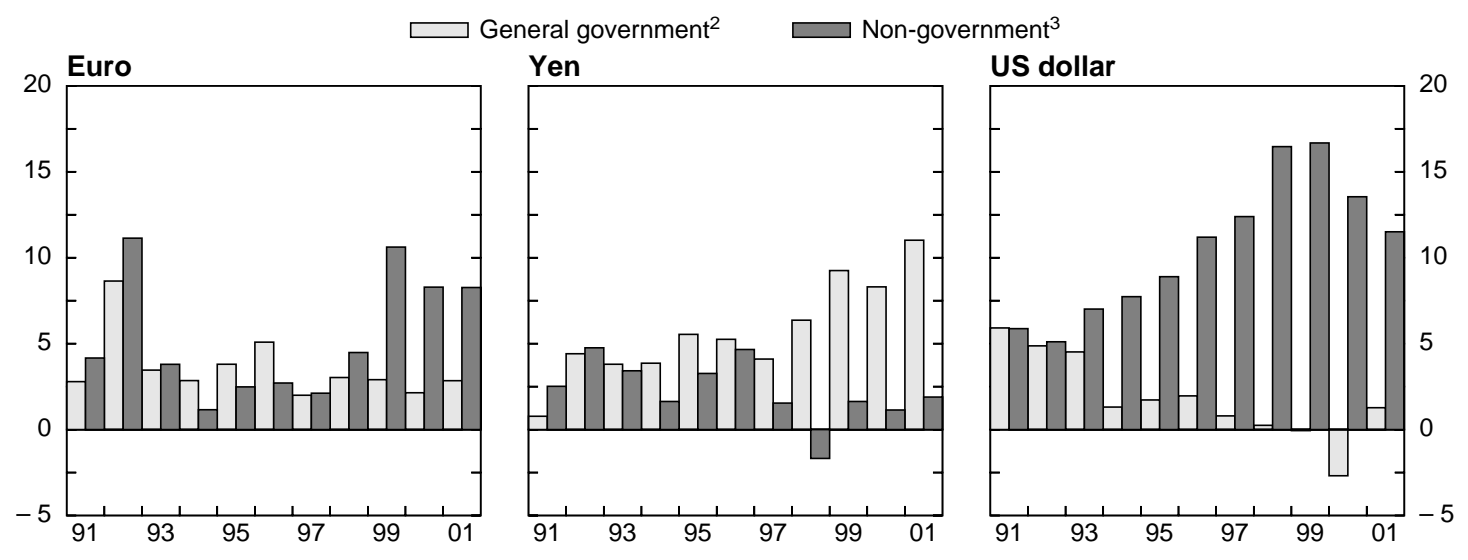

\footnotetext{
${ }^{1}$ Net issuance of money market instruments and bonds in domestic and international markets. ${ }^{2}$ Central governments, local governments and central banks. Data exclude issues by foreign governments. ${ }^{3}$ Non-financial corporations, financial institutions, government-sponsored enterprises and supranational institutions.
}

Sources: Bank of England; Dealogic; Euroclear; ISMA; Thomson Financial Securities Data; national data; BIS calculations.

\section{Electronic trading}

Another potentially far-reaching development in financial markets was the establishment of electronic trading platforms as a viable, if not superior, alternative to traditional means of trading. Some markets moved towards automated order routing, trade execution and information dissemination as early as the 1980s, but it was in the late 1990s that the electronic revolution was most impressive and visible. While its adoption across different markets has been very uneven, electronic trading has influenced the functioning of all financial markets to some extent. 
The foreign exchange market and derivatives exchanges were among the first to be transformed by new digital and telecommunications technologies. By 2001, up to $70 \%$ of interbank trading in the major foreign currency pairs was conducted through electronic brokers, compared to approximately $10 \%$ in 1995 (Galati (2001)). In derivatives markets, the shift in the trading of the bund futures contract from the London International Financial Futures and Options Exchange, which then still relied on open outcry, to Eurex, an electronic exchange, decisively demonstrated the advantages of electronic trading. The new technologies have now spread to money and bond markets, led by government markets, which have historically been the most actively traded segment. Equity markets too have seen electronic trading steadily displace floor trading.

Recent technological innovations are affecting the functioning of financial markets in two fundamental ways. ${ }^{5}$ First, they are sharply reducing the costs of transacting and of obtaining information. Transactions can be executed quickly, settlement can be completely automated, and some platforms allow for automatic hedging and arbitrage through direct links with futures markets. Perhaps more importantly, dealers can instantly identify the best available price, monitor quotes continuously, and if the order book is disclosed, even construct demand or supply schedules.Second, the new electronic systems are altering the relationship between dealers and end investors. In particular, they are blurring the demarcation between the inter-dealer market and the dealer-customer market. Some electronic platforms restrict participation to dealers and thereby maintain the traditional separation. Such interdealer systems typically require participants to fulfil market-making obligations, and exclude corporate and institutional customers. Single-dealer platforms, in which wholesale customers transact through a single bank's trading network, also perpetuate the segmentation of markets. By contrast, multi-dealer and open systems more closely integrate the inter-dealer and dealer-customer markets. Both multidealer and open platforms are open to all market participants who meet minimum eligibility requirements. But whereas open systems allow all participants to post prices, multi-dealer systems permit only dealers to post prices; all other participants are price takers.

As shown in Table 1, a multiplicity of proprietary systems are currently in operation (and many others have already failed). Eventually electronic trading in fixed income and foreign exchange markets is likely to concentrate in just a few systems. However, it is not yet clear which type of platform will come to dominate. The impact of electronic trading on market functioning could well depend on which type emerges as the market favourite.

Table 1

Selected electronic trading platforms

\begin{tabular}{l|l|l|l}
\hline \multicolumn{1}{c|}{ Type of platform } & \multicolumn{1}{c|}{ Equities } & Fixed income securities & \multicolumn{1}{c}{ Foreign exchange } \\
\hline Single-dealer & & $\begin{array}{l}\text { Autobahn (Deutsche) } \\
\text { eXpress (JP Morgan) } \\
\text { PrimeTrade (CSFB) }\end{array}$ & $\begin{array}{l}\text { FX Trader (UBS Warburg) } \\
\text { iFX Manager (BoNY) } \\
\text { WebET (Goldman Sachs) }\end{array}$ \\
\hline Inter-dealer & & $\begin{array}{l}\text { BrokerTec } \\
\text { eSpeed } \\
\text { EuroMTS }\end{array}$ & $\begin{array}{l}\text { EBS } \\
\text { Reuters Dealing 2000-2 }\end{array}$ \\
\hline Multi-dealer & $\begin{array}{l}\text { Bloomberg BondTrader } \\
\text { MarketAxess } \\
\text { TradeWeb }\end{array}$ & $\begin{array}{l}\text { Currenex } \\
\text { FXall } \\
\text { FX Connect }\end{array}$ \\
\hline \multirow{2}{*}{ Open } & $\begin{array}{l}\text { Euronext } \\
\text { Hong Kong Exchange } \\
\text { Instinet }\end{array}$ & $\begin{array}{l}\text { Eurex } \\
\text { SWX Eurobond }\end{array}$ & \\
\hline
\end{tabular}

Sources: Bond Market Association (2001), Claessens et al (2001), O'Hara (2001), Rutter et al (2002).

5 A report by the Committee on the Global Financial System (CGFS (2001a)) provides a more detailed examination of the potential impact of electronic trading on the structure, dynamics and stability of financial markets. See also Allen and Hawkins (2002) and Allen et al (2001). 


\section{Constellation and behaviour of market participants}

The current shape of financial markets has also been influenced by shifts in the diversity of investors and strategies active in markets. Bank mergers, financial crises and the growth of institutional investors have affected not only the constellation of market players, but also the risk management practices and investment strategies that these players follow.

Over the past decade, there have been a large number of mergers and acquisitions in the financial services sector of most industrial countries. 6 This has affected market functioning in a variety of ways. First, there are now fewer banks that can quote two-way prices. For example, whereas in the mid-1990s there were more than 50 global players in the foreign exchange market that were able to make markets in any currency pair at any time, there are currently no more than 20 (Galati (2001)). Second, financial consolidation frequently results in a withdrawal of risk (economic) capital allocated to market-making activities. Third, consolidation can make it more difficult to diversify counterparty credit risk. Particularly in over-the-counter derivatives markets, trading is highly concentrated among a handful of dealers. For example, following the merger of Chase Manhattan and JP Morgan in 2000, the combined entity's share of the interest rate swap market equalled nearly $25 \%$ (Swaps Monitor (2000)). Likewise, mergers invariably lead to lower credit limits than the sum of the limits that customers had assigned to the unmerged entities. This increases the probability that credit limits will become binding, and so may restrain customers' trading activity.7 Finally, consolidation may increase oligopolistic practices and the possibility of "gaming", not least in money markets.

While financial sector consolidation has reduced the number of dealers, other types of players have become more active in financial markets. In particular, institutional investors - pension funds, insurance companies, mutual funds, and other non-bank financial intermediaries - play a more prominent role today. For example, between 1995 and 2000, the total number of mutual funds in existence worldwide (excluding funds of funds) increased by $53 \%$ to 53,450 , and assets under management increased by $126 \%$ to $\$ 12.2$ trillion (Investment Company Institute (2001)). The euro area arguably experienced the greatest change. Bank deposits and other low-risk investments were traditionally the savings vehicle of choice in the euro area, but retail and other investors are increasingly placing their funds with professional asset managers. The result has been more diversified portfolios and a growing appetite for credit risk (BIS (2001b)).

Changes in the range of players active in markets have been accompanied by changes in risk management practices. To a large extent, these latter changes were precipitated by traumatic events, most notably the near collapse of Long-Term Capital Management (LTCM) in September 1998. In a report on the events of 1998, the Committee on the Global Financial System (CGFS (1999b)) notes that the LTCM crisis exposed the shortcomings of certain financing, trading and hedging techniques common in markets at that time. This led market participants to re-examine their risk management practices. For example, increased sensitivity to liquidity risk and to correlations across risks made market participants less willing to take directional positions in expectation of a rise or fall in a specific asset's price. The demise of global macro hedge funds in the wake of the LTCM crisis - three of the most celebrated hedge funds (LTCM, Tiger and Quantum) closed or restructured - is indicative of this change in investment philosophy (Tsatsaronis (2000a) and Graph 2). One consequence has been a reduction in the number of players likely to take a contrarian view.

6 A report by the finance ministry and central bank deputies of the Group of Ten (G10 (2001)) provides an exhaustive discussion of financial sector consolidation and its effects. Hawkins and Mihaljek (2001) examine financial sector consolidation in emerging economies.

7 The eventual outcome could be the migration of over-the-counter trading to an organised exchange, where a central clearing house could act as the counterparty to all trades (McCauley (2001)). 


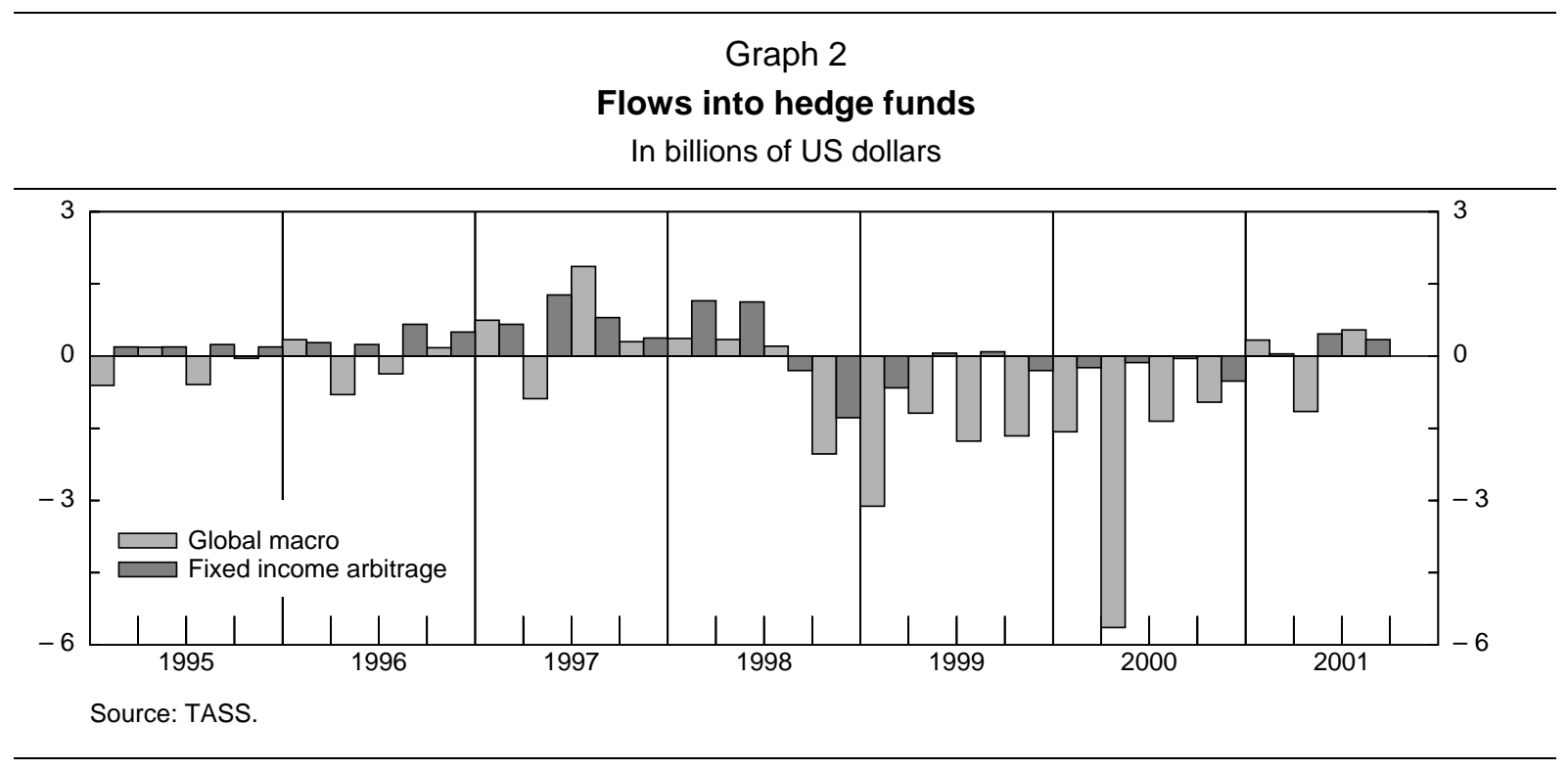

Other traumatic events that left a lasting imprint on market participants' risk management practices included the first ever corporate bond defaults in Japan and unexpected declines in the supply of US Treasury securities. Yaohan, a large Japanese retailer, defaulted on its publicly traded bonds in September 1997, and several Japanese banks followed suit in subsequent months. These defaults called into question the guarantees that trustees had implicitly provided in the past for yen corporate bonds (Hattori et al (2001)). Consequently, Japanese investors began to pay greater attention to the credit quality of issuers. In the US dollar market, the Treasury's announcement in February 2000 that it would auction fewer 30-year bonds and concentrate buybacks at the long end of the curve seemed to catch market participants by surprise, inducing some market stress. Episodes of this sort accelerated the substitution of private instruments for government instruments as hedging vehicles and pricing benchmarks in bond markets.Even while traumatic events have discredited some once-routine investment strategies, others have gained in popularity. Index tracking is one example. Equity, bond and other financial market indices were originally intended to summarise price changes for a broad basket of securities, ie to measure the "mood" of the market. Increasingly, indices are being used as performance benchmarks. Some portfolio managers deliberately attempt to replicate an index in its entirety. Other managers have their performance measured against an index, and so have an incentive to minimise deviations when constructing their portfolios. In their contribution to this volume, Clerc, Drumetz and Haas outline how widespread adherence to such a strategy could distort the price discovery process.

\section{Shifts in supply}

A final development of note in financial markets is shifts in the supply of available instruments. These have been especially important in fixed income markets and related segments (BIS (2001b)). Outside Japan, where it actually accelerated, net issuance of government securities slowed to its lowest level in decades by 2000. At the same time, issuance by corporations, financial institutions and other non-government borrowers soared (Graph 1). As a result, between 1995 and 2000 the outstanding stock of debt securities issued by industrial country governments fell from $45 \%$ of all debt securities issued worldwide to $35 \%$. The types of instruments issued have also changed. US Treasury-like issues from big non-government borrowers, new securitisation vehicles such as asset-backed commercial paper, and various credit derivatives have all gained broad market acceptance.

The shift in the supply of government debt has reflected widespread fiscal consolidation, breaking a previous long-standing trend. Beginning in the 1970s, government securities markets in many industrial countries had experienced a long period of expansion. Fiscal deficits had led to the large-scale issuance of treasury bills and bonds, and government debt managers and market participants alike had grown accustomed to ever increasing supplies of government debt. In the late 1990s, government securities markets contracted fastest in Australia, Canada, Sweden, the United Kingdom, the United States and other industrial countries with fiscal surpluses. Fiscal deficits in France, Spain and other euro area countries served to maintain the size of the euro-denominated 
market. At the other end of the spectrum, large deficits in Japan produced the world's biggest government bond market. The global economic slowdown in 2001 undermined the fiscal position of many governments, but they remain committed to keeping their deficits low.

In contrast to government issuance, bond issuance by non-government entities rose to record levels. The non-US Treasury segment of the US dollar market nearly doubled in size between 1995 and 2000 , to $\$ 13.2$ trillion. Euro-denominated issuance by non-government entities rose noticeably following the introduction of the euro. Even the outstanding stock of yen-denominated non-government securities expanded modestly in the late 1990s.

To the extent that government borrowing "crowds out" private borrowing, the falling supply of government bonds may have contributed to the strong growth of non-government markets. This seems to have been the case at least in the United States (BIS (2001b)) and, as noted in the accompanying paper by Edey and Ellis, in Australia. Indeed, in the US dollar and euro markets, big European, US and supranational borrowers have competed to provide liquid assets that could play some of the roles traditionally performed by government securities, notably as hedging instruments and pricing benchmarks. A key question going forward is how smoothly private debt markets will take over the broad set of functions previously performed by government securities, including that of safe haven at times of stress.

The growth of non-government markets may also have been assisted by the development of markets for transferring credit risk, in particular the credit derivatives market. Credit derivatives allow credit risk to be unbundled from other risks, traded in standardised markets and rebundled into new products that better meet the needs of investors (Rule (2001)). The credit derivatives market, which only came into existence in the early 1990s, had expanded to $\$ 694$ billion in terms of notional principal by end-June 2001 (BIS (2001b)). It remains much smaller than other derivatives markets: for example, the over-the-counter market for interest rate derivatives stood at $\$ 76$ trillion in notional terms at end-June 2001. Nevertheless, credit derivatives have the potential to become a benchmark for pure credit risk and as such are increasingly driving the pricing of credit risk in financial markets. In turn, their growth has been part of the broader trend towards heightened awareness of credit risk in the emerging environment as well as reflecting efforts to economise on regulatory capital.

\section{Implications for market liquidity}

Against the background of the structural changes just outlined, two questions loom large. First, how have these changes affected market liquidity in various market segments? Second, if liquidity has been shifting, can we draw lessons about its robustness? In particular, could liquidity be adequate in good times but have become more vulnerable under stress (the so-called "fair-weather hypothesis")?

\section{How has liquidity been shifting?}

For the reasons explained in Section 3, measuring liquidity is not straightforward. Even so, an examination of various indicators would suggest that, at least as measured in tranquil times, since the Asian and LTCM crises, liquidity has indeed been evolving in various market segments. In particular, with the exception of some emerging market currencies (Galati (2000)), liquidity does not appear to have changed much in foreign exchange markets. By contrast, it seems to have declined in the US government bond market and, on balance, to have risen in segments of the euro government bond market. Generally, swap markets appear to have gained in liquidity.

For foreign exchange markets, indirect measures of liquidity provide mixed evidence. The latest triennial survey of foreign exchange and derivatives market activity shows that global turnover declined markedly between 1998 and 2001 (Table 2). This is the first time that trading volumes have fallen since the first comprehensive survey was conducted in 1989. In addition, in their contribution to this volume, Chaboud and Weinberg present evidence that exchange rate volatility measured at very high frequency has increased in recent years. At first glance, these developments might imply that markets have become less liquid. However, according to market commentary, bid-ask spreads in foreign exchange markets have remained tight over the last few years, suggesting no change in liquidity (Galati (2001)). 
Table 2

Global foreign exchange market turnover ${ }^{1}$

Daily averages in April, in billions of US dollars

\begin{tabular}{l|r|r|r|r|r}
\hline \multicolumn{1}{c|}{ Instrument } & $\mathbf{1 9 8 9}$ & $\mathbf{1 9 9 2}$ & $\mathbf{1 9 9 5}$ & $\mathbf{1 9 9 8}$ & $\mathbf{2 0 0 1}$ \\
\hline Spot transactions & 317 & 394 & 494 & 568 & 387 \\
Outright forwards & 27 & 58 & 97 & 128 & 131 \\
Foreign exchange swaps & 190 & 324 & 546 & 734 & 656 \\
Estimated gaps in reporting & 56 & 44 & 53 & 60 & 36 \\
$\begin{array}{l}\text { Total "traditional" turnover } \\
\begin{array}{l}\text { Memo: Turnover at April 2001 } \\
\text { exchange rates }\end{array}\end{array}$ & $\mathbf{5 9 0}$ & $\mathbf{8 2 0}$ & $\mathbf{1 , 1 9 0}$ & $\mathbf{1 , 4 9 0}$ & $\mathbf{1 , 2 1 0}$ \\
\hline
\end{tabular}

1 Adjusted for local and cross-border double-counting. ${ }^{2}$ Non-US dollar legs of foreign currency transactions were converted into original currency amounts at average exchange rates for April of each survey year and then reconverted into US dollar amounts at average April 2001 exchange rates.

Source: BIS (2002).

Among fixed income markets, there is evidence of a decline in liquidity in the US Treasury market. In particular, Fleming (2001) shows that in the inter-dealer segment of the US Treasury market quote sizes for two-year, five-year and 10-year notes began to decline in the second half of 1998 (Graph 3). Turnover in the cash market also slowed down. More importantly, the impact of a given trade on prices became stronger. Similar trends are present in the Treasury futures market. The picture in Australia is more mixed. In their accompanying paper, Edey and Ellis find that liquidity in the cash market has deteriorated, but liquidity in the futures market has improved, so overall liquidity in the Australian government securities market is more or less unchanged. In Japan, liquidity in the JGB market appears to have remained essentially unchanged too (BIS (2001b)).

\section{Graph 3 \\ Liquidity of US Treasury securities}
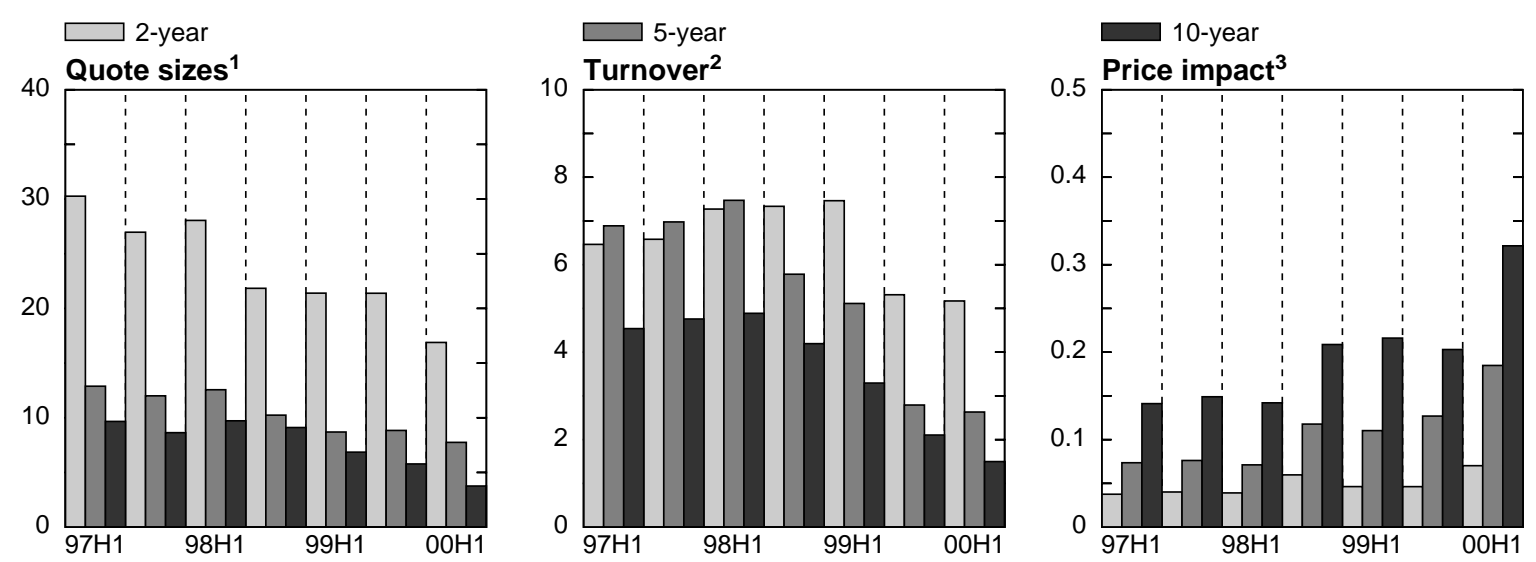

${ }^{1}$ Average quantity of securities bid or offered during the period, in millions of US dollars. ${ }^{2}$ Average daily turnover, in billions of US dollars. ${ }^{3}$ Basis points per trade.

Source: Fleming (2001), based on GovPX data.

By contrast, in the euro area the evidence points to a rise in liquidity in certain segments. In an apparent anticipation of the single currency in Europe, turnover on German bund futures began to surge before 1999 and, as discussed in the paper by Schulte and Violi, the contract has since become 
the most actively traded derivative in the world. Likewise, yield curves for government bonds have become smoother over time. In 1999, these yield curves tended to be jagged in shape and should have invited arbitrage activity between maturities had there been enough liquidity (Graph 4). By January 2001, most of these curves were smooth so as to suggest that there was enough liquidity to allow the trading that would eliminate arbitrage opportunities. In his contribution to the volume, Blanco finds that among euro area government securities markets, the German market has benefited the most from the improvements in liquidity brought about by the euro. French government bonds were more liquid at maturities of less than 10 years in the months following monetary union, but by 2001 German bonds had established themselves as the most liquid in all maturity ranges.

\section{Graph 4}

\section{Euro area government bond yields}

Spreads over swap rates, in basis points

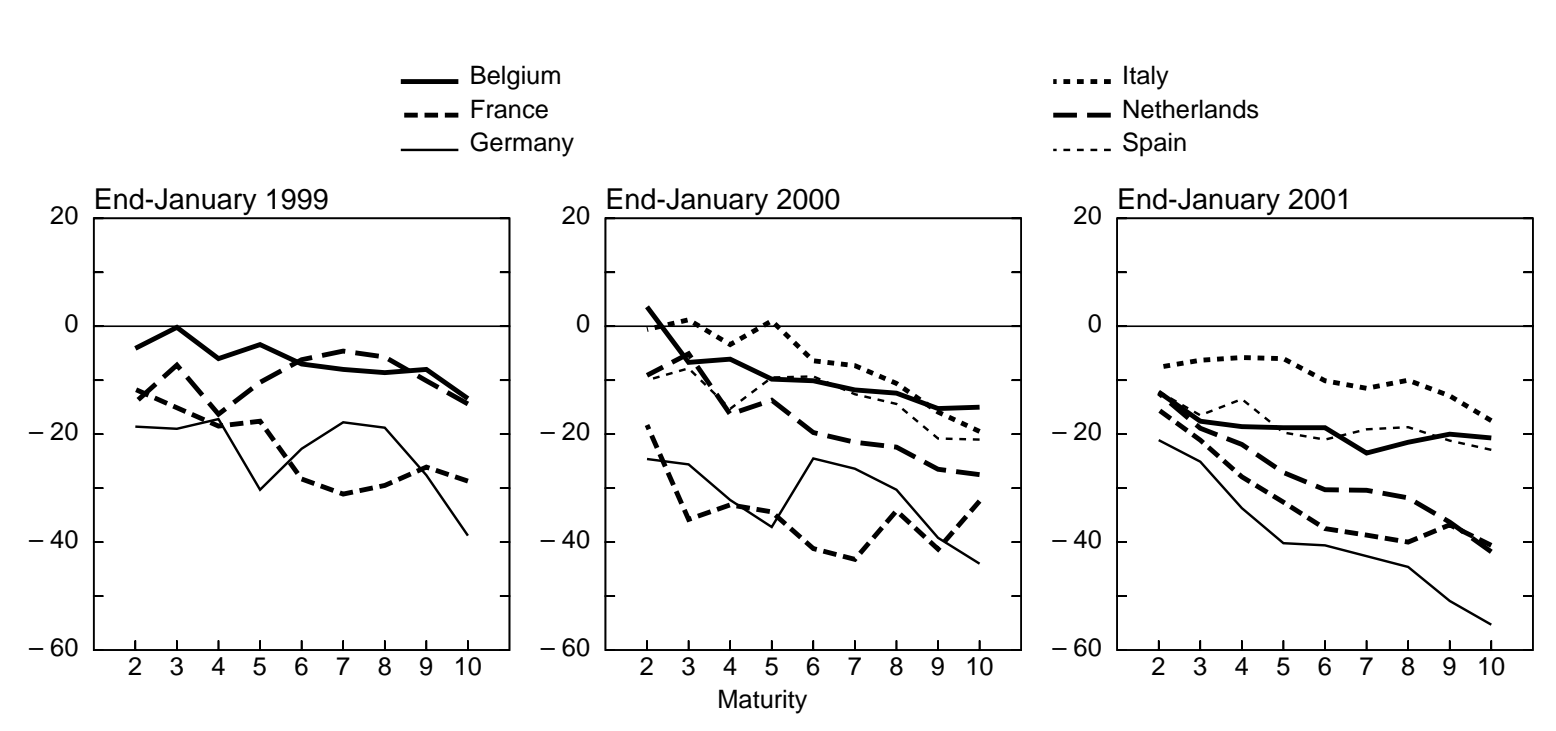

Sources: Bloomberg; Datastream; BIS calculations.

\section{What determines market liquidity in normal times?}

What factors may account for the observed changes in liquidity patterns? Consider in turn changes in relative supplies, changes in risk management, shifts in the population of market participants, notably through financial consolidation, and the spread of electronic trading platforms.

The previous picture is generally consistent with the view that, ceteris paribus, size, and hence changes in relative supplies, matters (McCauley and Remolona (2000)). ${ }^{8}$ Developments in the United States and the euro area support this conclusion. Likewise, while so far liquidity in the Australian market does not appear to have declined overall, Edey and Ellis note that the government is committed to maintaining a critical amount of debt outstanding, regardless of the fiscal position. At the same time, the stable liquidity conditions in the Japanese market are a reminder that other structural factors are important too. Moreover, even in the US Treasury market, trading activity seems to have picked up, and liquidity indicators to have improved, during 2001 as the size of the market continued to contract.

8 Like liquidity, market size has several dimensions. McCauley and Remolona (2000) discuss the relevance of various measures of size for liquidity. 
Changes in risk management practices have been highlighted as a potentially important factor leading to a reduction in liquidity. In particular, institutions appear to have withdrawn some of the capital devoted to market-making and own trading activities (CGFS (2001b)). This in turn seems to have reflected several factors, including a keener appreciation of risk/return trade-offs, shareholders' distaste for the high volatility of the earnings associated with these activities, and the traumatic experience of the market turbulence of 1998. In addition, the introduction of electronic trading platforms may also have played a role (see below). At the same time, the absence of a generalised evidence of a decline in liquidity points to two considerations. First, the withdrawal of market-making capacity has probably been uneven. Independent evidence, for instance, suggests that it may have been more significant in the US Treasury market, as indicated by the withdrawal of a large marketmaker in the first half of 1998. Second, and more importantly, the implications of withdrawal of marketmaking capacity may become more apparent under stress, when prices move outside normal ranges.

Changes in the constellation of market participants may also have contributed to a reduction in liquidity, as already anticipated in Section 3. For one, the changing characteristics of the surviving hedge fund population have arguably reduced the amount of quasi-liquidity services that these players supply, at least in tranquil conditions, by standing prepared to take the other side of transactions through their own trading. ${ }^{9}$ In addition, financial consolidation may have led to a further withdrawal of liquidity services. Consolidation has reduced the number of independent market-makers, reportedly contributing to the withdrawal of risk capital from market-making and trading, and led to a reduction of aggregate counterparty credit limits. Indeed, as highlighted by D'Souza and Lai in their analytical contribution, there are good reasons to believe that bank consolidation could lead to such a withdrawal of capital, although this result is by no means necessary. Here again, however, the impact of consolidation may be more apparent under stress conditions.

The effect of new electronic trading platforms on liquidity is an unresolved question. On the one hand, through their greater efficiency and cost-effectiveness, these platforms can increase participation in markets and reduce transaction costs. This could help to improve market liquidity, especially market tightness. On the other hand, by reducing the informational advantage traditionally enjoyed by dealers, these systems could reduce their incentive to make markets. In particular, in over-the-counter markets, dealers were traditionally better informed than customers, and so price discovery took place in the inter-dealer segment. The spreading of electronic broking systems in these markets can enable a broader set of participants to know instantly the best prices available at any point in time. As a result, market-making could become less profitable and attractive. Market depth could suffer even as tightness improved. The effects of these changes, however, might become visible only under stress.

\section{How does market liquidity behave under stress?}

As the previous discussion suggests, the concerns expressed in recent years that changes in financial markets may have made liquidity adequate in good times but more vulnerable in bad times have largely been based on two arguments. The first has stressed the shift from quote-driven to order-driven markets and, in addition, the potential decline in the profits of dealers which have gone hand in hand with the spreading of electronic trading platforms. The second has stressed a broader constellation of factors, with particular emphasis on risk management practices.

The first argument notes that market depth is likely to be greater in quote-driven markets because of the presence of market-makers whose role is precisely to quote two-way prices and iron out order imbalances. By contrast, in order-driven markets liquidity provision is more diffused, deriving from the limit orders entered into a centralised system. In systems where no participant has either an obligation or an incentive to make markets, the availability of liquidity will then depend on whether well informed and well capitalised investors can be expected to take the other side in an incipiently one-sided market. Moreover, to the extent that the introduction of electronic platforms undermines, directly and indirectly, the returns from market-making, it could reduce the incentive to provide liquidity services, especially under stress.

9 Such quasi-liquidity services could be provided either as part of their "contrarian" position-taking or, more specifically, through systematic "liquidity" arbitrage, taking offsetting positions in securities of similar characteristics except for their liquidity. Note, in addition, that in foreign exchange markets, carry trades were very common in the run-up to the Asian crisis. In this case, of course, liquidity was ultimately provided by the monetary authorities' defence of the peg. 
It is still unclear, however, how far these concerns are justified. The accompanying paper by Jiang, Tang and Law examines trading activity on the Hong Kong Futures Exchange before and after the migration to an electronic order matching system. They find that the electronic system has provided better liquidity during normal times, but that, at least relative to floor trading, the performance of the system has deteriorated during periods of high volatility or large volumes. More generally, analysis of the experience during the 1987 stock market crash proved inconclusive on this issue (OECD (1989)). One reason for this is that it is unreasonable to expect market-makers to continue to maintain market depth even in the presence of major imbalances, when their capital would be most at risk. Similarly, a recent CGFS study on electronic trading concluded that, while deserving close monitoring as they continue to evolve, electronic platforms had successfully coped with a number episodes of sharp price adjustments (CGFS (2001a)). Finally, it could also be argued that in quote-driven decentralised markets liquidity may in fact be more vulnerable, to the extent that it depends crucially on the financial strength of the main liquidity providers (Borio (2000)). Other things equal, this vulnerability is more of a concern if market-making is highly concentrated. In 1990, the consequences of the demise of Drexel Burnham Lambert, the key market-maker in the high-yield segment, illustrated most vividly the risks of concentration.

The second argument emphasises that the determinants of liquidity under stress are rather different from those in normal times (Borio (2000)). In particular, at times of stress concerns with counterparty risk and funding liquidity constraints, including those arising from the management of collateral, become much more binding than in tranquil times. Likewise, other risk management limits, such as value-at-risk constraints and stop-loss mechanisms, bite more strongly. The mutually reinforcing nature of these factors can, in extreme circumstances, lead to the complete evaporation of liquidity, as trading grinds to a halt amid higher volatility (Breedon (2001)). As in traditional bank liquidity crises, actions that may appear reasonable from the viewpoint of individual institutions exacerbate the perverse price and liquidity dynamics. According to this view, the state of liquidity in good times carries little information about its behaviour under duress. Indeed, ample market liquidity in a tranquil period may actually signal heightened vulnerabilities. This is so if it is accompanied by overextension in balance sheets. In this case, abundant liquidity would be a form of liquidity illusion, ie a symptom of market participants' excessive appetite for risk and of their underestimation of the build-up of risk in the system. It is precisely this overextension that provides the necessary wood for the fire.

Experience with episodes of market stress confirms the relevance of these factors. They were in evidence during the 1987 stock market crash and again during the 1994 bond market crash (Borio and McCauley (1996)). More recently, they were clearly at play during the 1998 market turbulence, which affected especially US fixed income markets (CGFS (1999b, 2001c)). So far, however, rigorous econometric analysis of the recent episode has been very limited. And most of it has been carried out by researchers in the central banking community, not least since the academic literature has only begun to come to grips with the analysis of perverse market dynamics under stress (Genotte and Leland (1990), Morris and Shin (2000), Danielsson et al (2001)). Data limitations have been a severe constraint.

On the basis of this recent work, some of the features of the 1998 turbulence are becoming clearer. In their contribution to this volume, Upper and Werner conclude that during the October 1998 crisis the German bund futures market on Eurex proved rather robust to extreme volatility. ${ }^{10}$ Trading costs did rise, but the pricing relationship between the futures and spot market remained comparatively stable, at least with respect to the underlying that was cheapest to deliver. The relationship did break down, however, with other bonds, including the on-the-run issue. The accompanying paper by Cohen and Shin finds that during the 1998 market turbulence positive-feedback trading in the US Treasury market became more pronounced. Moreover, Furfine and Remolona (2002) show that dealers scaled back their quote sizes asymmetrically, with ask sizes being reduced more than bid sizes, and that they relied more on negotiated trade sizes ("work-ups") (Table 3). As trade frequency increased, overall volumes actually rose, a sign that the market did not freeze altogether.

10 See also Upper (2001). 


\section{Table 3}

Liquidity under stress

Daily market averages for the 5-year on-the-run US Treasury note

\begin{tabular}{|c|c|c|c|c|c|}
\hline & $\begin{array}{l}\text { May-Dec full } \\
\text { sample }\end{array}$ & Stress days $\mathrm{I}^{3}$ & Stress days $\|^{3}$ & Stress days $\mathrm{III}^{3}$ & $\begin{array}{c}\text { Stress days } \\
\text { IV }^{3}\end{array}$ \\
\hline $\begin{array}{l}\text { Number of } \\
\text { transactions }\end{array}$ & 662 & 786 & 887 & 745 & 738 \\
\hline $\begin{array}{l}\text { Number of hit } \\
\text { transactions }\end{array}$ & 342 & 406 & 462 & 379 & 370 \\
\hline $\begin{array}{l}\text { Number of take } \\
\text { transactions }\end{array}$ & 320 & 380 & 425 & 366 & 368 \\
\hline Dollar volume ${ }^{1}$ & 6,740 & 8,283 & 9,399 & 7,241 & 7,484 \\
\hline Hit volume $^{1}$ & 3,374 & 4,142 & 4,697 & 3,619 & 3,765 \\
\hline Take volume $^{1}$ & 3,366 & 4,141 & 4,701 & 3,623 & 3,719 \\
\hline $\begin{array}{l}\text { Inter transaction } \\
\text { times }^{2}\end{array}$ & 56.8 & 51.2 & 38.6 & 47.8 & 47.9 \\
\hline Ask depth ${ }^{1}$ & 9.84 & 9.20 & 9.22 & 7.55 & 8.07 \\
\hline Bid depth $^{1}$ & 9.53 & 8.66 & 8.22 & 7.49 & 7.77 \\
\hline
\end{tabular}

${ }^{1}$ In millions of US dollars. ${ }^{2}$ Measured in seconds between transactions. ${ }^{3}$ Stress days I are based on the JohnsonLowenstein events, stress days II on the Kho-Lee-Stulz exposed bank stock returns, stress days III on the Reinhart-Sack credit spreads, and stress days IV on increases in swap yields.

Sources: Furfine and Remolona (2002), based on GovPX data.

Some changes in risk management practices since the market turbulence of the autumn 1998 suggest that national authorities and market participants are beginning to address a number of the shortcomings that exacerbated the stress. Examples include improved counterparty risk assessment as well as collateral and liquidity management, including through greater reliance on stress testing (CRMPG (1999)). Moreover, there is some evidence that institutions have become more aware of the risks of automatic reliance on limits that arise from the interdependence among market participants (CGFS (2001d)). Even so, the ultimate causes of the evaporation of liquidity under stress are exceedingly hard to address (see below).

Looking forward, a related and yet unanswered question concerns the characteristics of a flight to quality under stress in a world in which government securities could become scarce (BIS (2001b), Schinasi et al (2001)). The question is pertinent given the declining supplies of some government securities. The dynamics of the flight to quality would be likely to depend on the particular assets that investors choose to move into. These dynamics would also be likely to change if collateral no longer took the form of a default-free asset. At the same time, Wojnilower (2000) suggests that the absence of such an asset would reduce the willingness of investors to bear risk even during normal times.

\section{Implications for asset pricing}

Three questions concerning the implications of recent changes in market functioning for asset pricing merit particular attention. First, what has been the impact of changes in market segmentation and integration? The effects brought about by the creation of the euro are especially important. Second, how has the information about fundamentals reflected in asset prices changed? Of particular interest here is how well yield curves in various fixed income markets reflect expectations about macroeconomic fundamentals, notably facilitating the identification of the evolution of expected future rates and estimates of the default-risk free rate. Finally, given the new prominence of credit risk, which 
markets are best informed about this risk? The consistency of the information derived from different prices is especially relevant.

\section{What can prices tell us about market integration and segmentation?}

A key question since the establishment of the euro has been to what extent the introduction of the new currency has promoted the integration of different market segments. Pricing relationships can be used to cast light on this issue. In a fully integrated market, instruments with the same characteristics should command the same price.

As regards the equity market, the accompanying paper by Emiris finds that the degree of integration had already been increasing before the introduction of the single currency. Tsatsaronis (2001) and Galati and Tsatsaronis (2001) show that the process accelerated measurably following the advent of the euro, with sectoral factors superseding country factors in determining pricing (Graph 5). At the same time, there is evidence that, at least qualitatively, this trend has affected equity markets more globally in recent years.

\section{Graph 5}

Changes in the relative importance of country and sector factors in the determination of equity prices

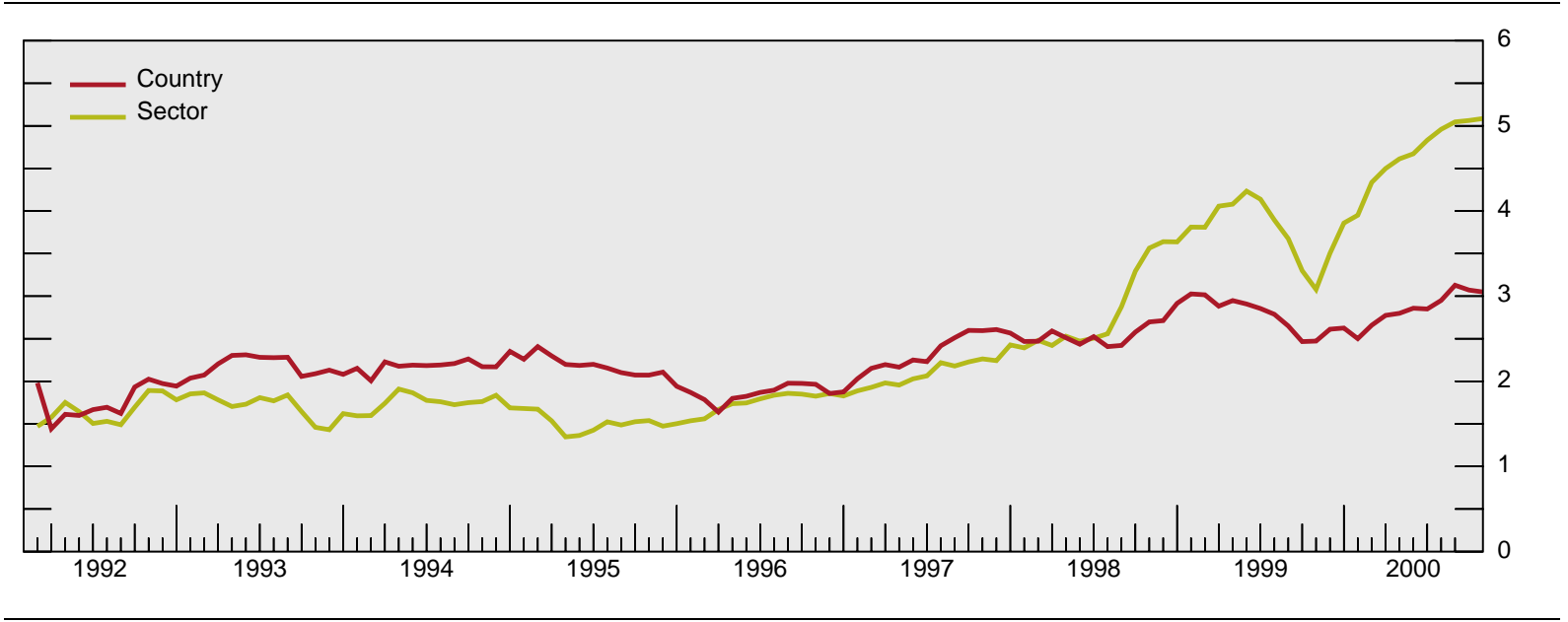

Source: Tsatsaronis (2001).

The impact of the creation of the euro on fixed income markets has been more profound. Even so, a number of papers stress that the integration of fixed income markets in the government segment has been less than complete. In fact, since the introduction of the new currency, spreads across bonds issued in different countries have actually widened. While credit factors may still play a role, differences in liquidity appear to be more important, as indicated most clearly by the fact that the yields cross at different maturities (Galati and Tsatsaronis (2001)). As a result, a fully reliable government yield curve has not as yet taken shape. Blanco as well as Schulte and Violi examine these issues in detail in their contributions to this volume, looking also at the various factors that may impede full integration, and considering both cash and futures markets. An additional unsatisfactory aspect stressed in both contributions is the comparatively high potential for squeezes, not least owing to the large size of the futures relative to the cash market. This is still an unresolved issue.

\section{How well do various yield curves reflect macroeconomic expectations?}

Traditionally, government bond markets have reflected mainly public information, especially about macroeconomic developments and monetary policy actions. In contrast, equity markets have been more indicative of the earnings prospects of individual companies. Hence, government bond markets have had a comparative advantage in revealing expectations about macroeconomic fundamentals, while equity markets have had such an advantage in providing information about individual 
companies. In recent years, shifts in liquidity and changes in the mix of asset supplies may have altered the process by which these markets impound information and the way markets respond to price signals from other markets.

One way of identifying what information is reflected in asset prices is to examine how they respond to news. Other things equal, the stronger and more consistent the response to a particular type of information, the more likely it is that that information is reflected in the price.

In the past few decades, yield curves based on government securities were widely recognised as the pre-eminent benchmark for the cost of funds at different borrowing horizons. In industrial countries, price discovery about macroeconomic prospects occurred mainly in government securities markets rather than in equity markets. Thus, Fleming and Remolona (1999a, b)) show that prices in the US Treasury market were largely driven by macroeconomic announcements and monetary policy actions. ${ }^{11}$ Fair (2001) found that only a small fraction of the large changes in US stock prices were due to such macroeconomic announcements. As a result of the information reflected in the yield curve, Estrella and Mishkin (1998) were able to conclude that for predicting US recessions over horizons beyond one quarter, the slope of the US yield curve was the clear choice over other variables, including stock prices. Similar evidence was found for other countries too (Bernard and Gerlach (1996)). The existence of such a yield curve made it convenient to compare yields on instruments with different credit risks at a given maturity, and hence bonds issued by corporations, financial institutions and other non-government borrowers tended to be priced against this curve.

Admittedly, the usefulness of the yield curve has varied from one government bond market to another. The Swedish market, for example, seems to have behaved in a similar way to the US market. The accompanying paper by Andersson, Dillén and Sellin finds that in the Swedish market monetary policy signals play a key role along the yield curve. The Swiss market may have been different. In his contribution to this volume, Büttler fits a three-factor model of the term structure to yields in the Swiss government bond market and finds that the implied term structures for real short rates and inflation rates are hard to explain. But overall, the key role played by government yield curves in providing information about macroeconomic fundamentals was not generally challenged.

In recent years, however, some of the largest government securities markets have begun to lose their pre-eminence as the centres for price discovery about macroeconomic fundamentals. In particular, owing to the deterioration in liquidity in the US Treasury market, changes in issuance or buyback plans and unexpected safe haven flows have introduced idiosyncratic shocks. Because of the interference of these shocks, Reinhart and Sack find that yields in this market have become less informative about the risk-free rate. As a consequence, a search for alternative benchmarks is under way, with a range of non-government instruments being considered as potential candidates (Wooldridge (2001)).

In the search for alternative benchmarks, attention has been focused on the debt instruments of government-sponsored enterprises (GSEs) and on interest rate swaps. The bonds of GSEs such as Fannie Mae and Freddie Mac in the United States, or of similar institutions elsewhere, such as Kreditanstalt für Wiederaufbau in Germany, have high credit ratings and are relatively liquid. Some GSEs have seized the opportunity to provide benchmarks by issuing large amounts of debt at regular intervals across a range of maturities. Interest rate swaps are another possible alternative, especially with the decline in concerns about the credit risk of the dealers. Nonetheless, neither agencies nor swaps have so far been as successful as the government bond markets had been in providing meaningful yield curves. For example, in their contribution Reinhart and Sack also note that the information about fundamentals contained in agency and swap yields remains difficult to interpret, owing to the combined effect of different influences. They also suggest that information can best be gleaned if the movements of different yields are assessed jointly, by imposing identifying restrictions on the factors that they are supposed to reflect.

Looking forward, McCauley (2001) points to certain factors that would help swaps become the new pricing benchmark. First, new swaps of a given maturity are traded every day, so their maturity is constant from day to day, unlike the yield on an on-the-run agency bond. Second, new swap rates are quoted at par and are therefore not affected by the tax and accounting effects that influence secondary market prices for bonds. Admittedly, since they are unsecured interbank rates, swap rates

11 For an update of this study, see Furfine (2001). 
remain susceptible to changes in the credit quality of banks. Nevertheless, it appears that the use of swap rates as a pricing benchmark will probably continue to grow over time. This process appears to be furthest advanced in the euro market, where the interest rate swap curve has already emerged as the benchmark yield curve (BIS (2001b)). Even so, in his contribution Blanco suggests that in Europe the government yield curve might still continue to be more reliable as a source of information for macroeconomic fundamentals.

\section{Which markets are best informed about credit risk?}

The remarkable shift in the issuance of debt securities from government to private sector borrowers has gone hand in hand with greater attention being paid to the pricing of credit risk. The two most significant developments in this regard have been the growth of credit derivatives and the use of an approach to measuring credit risk that relies on information from stock prices. At the same time, credit derivatives, corporate bonds and stock prices do not seem to provide entirely consistent signals. The issue this raises in the short term is which market provides the most reliable signals. The longer-term issue is how price formation about credit risk is likely to evolve.

Before the introduction of credit derivatives, it was difficult to isolate credit risk from other factors, in particular from liquidity risk. In principle, credit derivatives facilitate the decomposition of corporate spreads into their various risks and give concrete form to the term structure of credit risk. They thereby allow price differences among similar securities to be exploited more efficiently. While credit derivatives themselves may have credit or liquidity premia, they have the potential to become a benchmark for pure credit risk. As such, they may increasingly drive the pricing of this risk. The accompanying paper by Marsh compares the default probabilities implied by spreads on corporate bonds with those implied by default swaps and finds significant differences. He attributes the differences partly to liquidity factors. In their contribution, Boss and Scheicher find that credit spreads in the euro area are driven by idiosyncratic factors as well as by macroeconomic factors that are reflected in German government bonds.

One of the notable developments in fixed income markets in 1999 and 2000 was the apparent emergence of a new link between credit and equity markets (BIS (2000), Cohen (2000)). In particular, credit spreads tended to widen in the wake of price declines and increases in volatility in equity markets. This phenomenon seems to have stemmed at least in part from an increasingly widespread use by fixed income dealers and institutional investors of an option-based approach to the estimation of credit risk. The approach, first proposed by Robert Merton in 1973 but only widely applied in recent years, derives a firm's default likelihood from the market value and volatility of its equity and its leverage. The approach relies on the idea that information about a firm's prospects would be reflected first in the stock market. Trends in 2000 and early 2001 in stock and corporate bond markets were roughly consistent with such an approach.

At the same time, whatever the influence of the new methods, the estimates of credit risk gleaned from movements in equity prices and credit spreads have not always been consistent. This was clearly evident, for instance, as 2001 progressed (BIS (2001a) and Graph 6). While equity prices fell markedly, credit spreads narrowed, resulting in divergent movements in the implied estimates of probabilities of default. As various methods for measuring credit risk become increasingly widespread and are incorporated into prudential standards, notably minimum capital requirements, differences in the messages derived from various market instruments will no doubt deserve greater attention. 


\section{Implied probability of default and corporate bond spreads} A-rated US companies

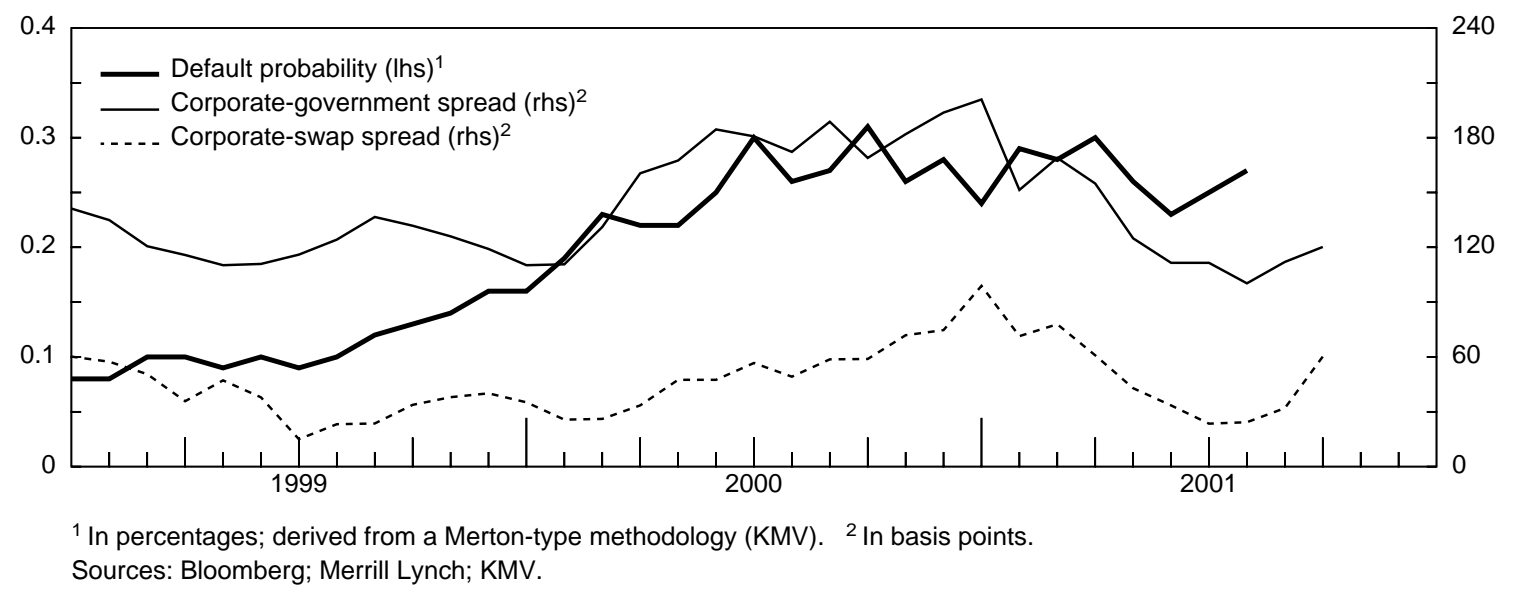

\section{Implications for central bank policies}

The changes in market functioning analysed in the previous sections raise a number of issues for central bank policies. One set of issues relates to the appropriate role that central banks should play in fostering well functioning markets, in particular in promoting robust market liquidity. Questions arise regarding both the prevention of market liquidity breakdowns and the response to episodes of stress. A second set of issues includes strategic and tactical aspects of monetary policy setting, such as the implications for the transmission mechanism, for the use of the information contained in asset prices as a guide to policy and for central banks' communication with the markets. A third set concerns central bank market operations, including domestic liquidity management operations, FX reserves management and foreign exchange intervention.

\section{Market liquidity}

Central banks have traditionally had a keen interest in promoting robust liquidity in financial markets. This has been predicated on the belief that liquid markets can facilitate their operations, improve the transmission mechanism of monetary policy impulses, make it easier to read market participants' expectations and contribute to financial stability. The range of instruments employed is very broad. It includes, inter alia, furthering the understanding of the determinants of market liquidity, encouraging or adopting improvements in financial infrastructure (eg trading platforms, clearing and settlement arrangements), advising or managing the government's debt management operations, and the choice of operating procedures (eg eligible collateral, choice of counterparties). This has largely been done at the national level but, increasingly, at the international level too. In this regard, the activities of the Committee on the Global Financial System are noteworthy (eg CGFS (1999c)). ${ }^{12}$

The contribution from Marès considers in more detail public policy towards market liquidity and the role of central banks. Marès stresses, in particular, the need for a comprehensive cost-benefit analysis. In addition, the analysis of liquidity under stress in the previous section suggests that ensuring robust liquidity is an exceedingly difficult task. Moreover, it requires the activation of instruments well beyond

12 An additional channel through which central banks can promote liquidity is through their influence on debt management operations by the government. However, in recent years there has been a tendency for this influence to become weaker, as responsibilities in this area have increasingly shifted to governments. 
the control of central banks. Given the importance of risk management practices, prudential authorities have a key role to play too. Two major, interrelated difficulties deserve attention (Borio (2000), Crockett (2001)). The first, as highlighted by Marès too, is that market liquidity tends to be procyclical with respect to financial market conditions. Its price is low in good times and can rise dramatically under stress. This tends to reinforce, rather than dampen, cycles in liquidity conditions. The second is that actions that may appear reasonable from the perspective of individual institutions may actually exacerbate the vulnerability of liquidity conditions. Generalised retrenchment at times of stress is an obvious case in point. This problem is entirely analogous to the broader one of the procyclicality of the financial system and prudential regulation generally (Borio et al (2001), Crockett (2000)). Addressing it involves better information, in the form of leading indicators of financial market stress, and better safeguards, in the form of safety cushions that can be built up in good times to be run down in bad times. These problems have only begun to be tackled. ${ }^{13}$

A separate, but just as difficult, question concerns the appropriate role of central banks in responding to episodes of stress in market liquidity, which would normally be associated with broader stress in markets. There is of course a consensus that central banks should facilitate the smooth functioning of markets. This is especially uncontroversial when the origin of the disturbances is clearly exogenous to the behaviour of participants, such as in the case of Y2K or of the terrorist attacks of 11 September 2001, which heavily disrupted normal market functioning. At the same time, in intervening central banks need to be quite conscious of the potential "collateral damage" in terms of moral hazard that may be associated with their actions (Crockett (2001)). Damage may arise not only, or indeed primarily, from the provision of emergency liquidity assistance but, more insidiously perhaps, from reductions in interest rates aimed at relieving pressure on markets. Making such a decision implicitly involves a judgment about the damage for the "real" economy inflicted by market malfunctioning. ${ }^{14}$ Central banks may position themselves differently along the spectrum of possible policy responses.

One factor influencing this choice will no doubt be which market is affected by the evaporation of liquidity. In general, central banks would care strongly about those markets that are critical for the implementation of policy; their paralysis could cripple the central bank's armoury. The interbank market for bank reserves is a clear case in point. Markets whose functioning is critical for the economy would also rank high. Their identity, however, would depend on the characteristics of a country's financial structure, including its connecting tissue with the rest of the world, and may even vary with circumstances. For example, the size and functions of the swaps market differ considerably across countries. Likewise, developments in the equity market may be relatively unimportant against the background of robust economic conditions, but could become pivotal if the economy was already fragile.

\section{The transmission mechanism}

The significance of the changes in market functioning for the transmission mechanism is not straightforward to identify or quantify. There is indeed some general evidence that the transmission mechanism may have been changing. For the United States, for instance, this has recently been documented by Barth and Ramey (2001) and Hanson (2000). Likewise, following the creation of the euro area, a network of central bank economists was formed to coordinate research on the transmission mechanism in the new currency area, culminating in a conference at the ECB in December 2001. Moreover, previous work has shown how financial structure can have significant implications for how monetary impulses are transmitted to the real economy (BIS (1995)). Even so, the marginal contribution of the changes in market functioning discussed above remains an open issue.

Kuttner and Mosser partly fill this gap. In their accompanying review of research concerning the impact of financial innovation on the monetary transmission mechanism, they conclude that financial

13 Indicators of financial market stress would most likely have to be based on the aggregation of risk management information from individual firms' risk management systems. A first step to consider this question has been taken by the CGFS, with reference to the possible aggregation of stress tests (CGFS (2000, 2001d)).

14 Other factors would be relevant too. One issue, for instance, is the risk of misinterpretation of the authorities' intention. For instance, even if exclusively interested in the consequences for the real economy, the central bank may be perceived to react to market illiquidity per se. The economic background against which the action is taken, such as whether the economy is already deteriorating for other, more fundamental reasons, could affect the choice. 
innovation has left the transmission mechanism unchanged in certain areas, even while the overall impact remains uncertain. Looking to the future, Clerc, Drumetz and Haas provocatively ask whether by improving hedging possibilities, the development of credit derivatives might not help insulate the economy from changes in policy interest rates, dampening their effect. This general issue, in fact, is not new. It was already raised in the past with respect to the development of instruments for the hedging of interest rate and exchange rate risks (Euro-currency Standing Committee (1994)) and has been subject to some empirical analysis (Fender (2000a, b)). But the answer still remains unclear.

Economic developments in Japan, however, remind us that some "old" questions related to the transmission of monetary policy remain. Namely, how does a central bank which uses an interest rate as a policy tool conduct policy when interest rates reach their zero lower bound, and how can a central bank most efficiently increase economy-wide liquidity when banks stop lending? In March 2001, the Bank of Japan switched its operating target from an overnight interbank interest rate to the average outstanding balance of current accounts at the Bank of Japan. The new policy seems to have had a more pervasive effect across the JGB term structure, while the narrowing of credit spreads as bond yields decline may be indicative of a search for higher returns induced by the more expansionary stance (Marumo et al (2002)).

Indeed, one might well ask whether this latter effect might not in fact be a distinguishing feature of the new landscape more generally. Specifically, in the new environment financial institutions have become much more conscious about the management of risk, notably credit risk, and default-free government debt may be losing its pricing benchmark role. If so, perceptions of risk, attitudes towards risk and the ability to take on risk may have become more important in driving economic activity (Borio et al (2001)). Consequently, measuring these factors and the impact of monetary policy actions on their evolution should receive more attention. ${ }^{15}$ Arguably, for instance, the link was evident in the swift response of financial markets to the reduction in interest rates by the US Federal Reserve following the financial turmoil associated with the difficulties at LTCM. Likewise, while the Fed's monetary easing in 2001 may have failed to boost equities, lower the dollar or ease Treasury yields much, it did appear to encourage demand for high-yield bonds, tightening spreads and unlocking issuance (BIS (2001a)).

\section{Information from and to markets}

In contrast to the implications for the transmission mechanism, those for the information content of asset prices are much more apparent. At least two of these implications can be highlighted. First, the development of new markets, such as those for credit derivatives, and the broadening and deepening of existing ones, such as those for corporate debt, have increased the range of possible sources of information. This has been further facilitated by the spreading of new methodologies for the assessment of risk, such as Merton-type methodologies to derive estimates of default probabilities from equity prices. Second, several developments have actually clouded the information content of traditional indicators, such as term structures of interest rates based on government debt instruments. Changes in relative supplies, shifting liquidity patterns, and the initial difficulties in forming an integrated bond market in the euro area have all contributed here. Moreover, the increased range of information per se at times appears to result in conflicting signals.

This has put central banks in a rather paradoxical situation: they have a broader spectrum of potential information from which to draw but face greater difficulties in interpreting it. A symptom of these difficulties is that two papers in the volume - Reinhart and Sack and Clerc, Drumetz and Haas - reach different conclusions regarding whether government bonds or swaps may now be more reliable indicators of expectations about the future course of risk free rates. A key issue is whether the difficulties faced are just transitional or whether they are likely to persist for the foreseeable future. Looking forward, the most promising area for further development arguably relates to the leading indicator properties of credit risk signals. If the previous argument about the role of risk perceptions in driving economic fluctuations is correct, then the value of the information contained in these signals is likely to increase. Empirical evidence from the United States appears to be consistent with this

15 See, for instance, BIS (1999) and Tsatsaronis (2000b) for an attempt to measure risk appetite and a possible link with monetary conditions. 
proposition (Gertler and Lown (2000)). ${ }^{16}$ Such indicators are also potentially very useful for central banks in terms of their responsibilities for financial stability.

Regardless of the information that central banks can receive from the markets, there seems to be a broad consensus that the greater role that financial markets now play in influencing economic activity puts a premium on the information that central banks should provide to them. In recent years, central banks have become increasingly transparent. For instance, inflation targeting regimes make very high demands on transparency, as discussed in the contribution by Bogdanski, de Freitas, Goldfajn and Tombini. Even so, articulating an appropriate communication policy is not straightforward. The accompanying paper by Andersson, Dillén and Sellin notes that speeches and releases of minutes can have a considerable impact on markets' future expectations about policy. Calibrating the information released and avoiding confusion may be difficult. Moreover, circumstances can arise in which central banks may wish to surprise markets, so as to magnify the psychological effect of their actions. Differences of views on these tactical questions, partly shaped by the constraints under which policies are formed, do appear to exist within the central banking community. Against this background, in their contribution to the volume Gaspar, Perez-Quirós and Sicilia examine the predictability of ECB policy moves.

\section{Domestic operations}

Turning next to the implications of changes in market functioning for domestic monetary operations, one issue that has come to the forefront is that of the range of eligible collateral. For structural reasons, scarcity of collateral is in fact a rather familiar issue for many emerging market countries, where the lack of an established securities market inhibits the use of repurchase-type operations in liquidity management. But it has also become a potential constraint in some of the industrial countries where the adjustment of structural deficits has led to a decline in sovereign debt issues, threatening the disappearance of the primary source of collateral. This is especially relevant for those countries without a (recent) tradition of relying also on private sector instruments as collateral, such as the United States and Australia, and which may also rely on the use of sovereign debt securities for permanent injections of liquidity, through outright purchases (Borio (1997)).

In turning away from domestic sovereign debt for their operations, central banks must confront at least two questions. ${ }^{17}$ The first, not faced by other market participants, is how to conduct operations without distorting market prices. Eligibility as collateral, by enhancing the liquidity of the corresponding instrument, in effect subsidises its issuer. In the extreme, the choice of securities used in operations may afford the issuer an undesirable advantage. These concerns have been particularly prominent in the United States, where government-sponsored enterprises have aggressively positioned their debt issues as alternatives to Treasury securities as risk-free instruments. Debates have ensued regarding the status of the GSEs' implied government guarantee and whether or not that implied guarantee amounts to an unfair subsidy. The second question, shared with other market participants, is how to address the default risk associated with non-government debt instruments. This requires setting up the infrastructure to measure and manage the corresponding credit risk.

In the event, the central banks faced with these questions have broadened the set of eligible collateral, by extending it either to additional domestic currency instruments (the United States and Australia) or to foreign currency ones (the euro in the United Kingdom). In some instances, they took advantage of the broadening of eligible collateral that had taken place at the time of the Y2K operations, turning it from temporary to permanent (Borio (2001)). In addition, some central banks have also relied more heavily on foreign exchange swaps. Edey and Ellis discuss in detail in their contribution how the Reserve Bank of Australia has addressed these issues.

16 In addition, Lown et al (2000) show that information gleaned from surveys of banks' perceptions of risk as reflected in nonprice terms of the loans helps to predict economic activity.

17 From a historical perspective, the use of government securities as collateral for central bank operations is actually of relatively recent vintage. In the early days of central banking, private sector instruments were the rule. This was dictated by the orthodoxy of the day, not least concerns with the financing of government deficits. It was only with the relaxation of this doctrine and the growth of the stock of public sector debt in the wake of government deficits that sovereign claims came to prevail in, and in some cases monopolise, operations. 
The increasing consolidation of the financial services industry also presents a problem for the conduct of domestic monetary policy operations (and external operations as well). The increased consolidation may lead to market pricing power, or even collusion, in the markets in which central banks conduct their operations. The Swiss National Bank, for instance, was forced to switch its policy target to an offshore interest rate, specifically Swiss franc Libor, once two large banks came to dominate the domestic market following a merger. The Bank of England, too, has had difficulties with non-competitive behaviour of securities firms in money markets. The accompanying paper by Allen discusses some of the resulting changes in interest rate volatility and the Bank of England's response.

\section{External operations}

External operations are affected by some of the same developments impinging on domestic operations. In particular, the falling stock of US Treasury securities presents a problem for central banks holding them as foreign reserves. There is some evidence that central banks have begun to diversify their dollar reserves into other instruments (Fung and McCauley (2000)). Between 1995 and 2000 , US dollar reserves held as GSE securities more than doubled to $5 \%$, while reserves invested in Treasuries fell to $59 \%$ (Table 4). Other alternatives to Treasury securities include the dollardenominated obligations of other sovereigns, corporate issues (including equity), asset-backed securities, interest rate swaps, credit derivatives and purchases of non-US sovereign debt combined with forward sales vis-à-vis dollars. In choosing among these alternatives, central banks face many of the risks mentioned previously. More generally, the shift away from default-free sovereign issues is itself part of a broader trend reflecting central banks' increasing attention to yield in the management of reserve assets, bringing them closer to strategies followed by private sector agents. The implications of this trend for market functioning have arguably not yet received the attention that they deserve. In his contribution to this volume, Visser examines how the Netherlands Bank has adjusted its reserve management practices to the challenges raised by the new environment.

Table 4

Composition of US dollar reserves

As a percentage of identified dollar reserves ${ }^{1}$

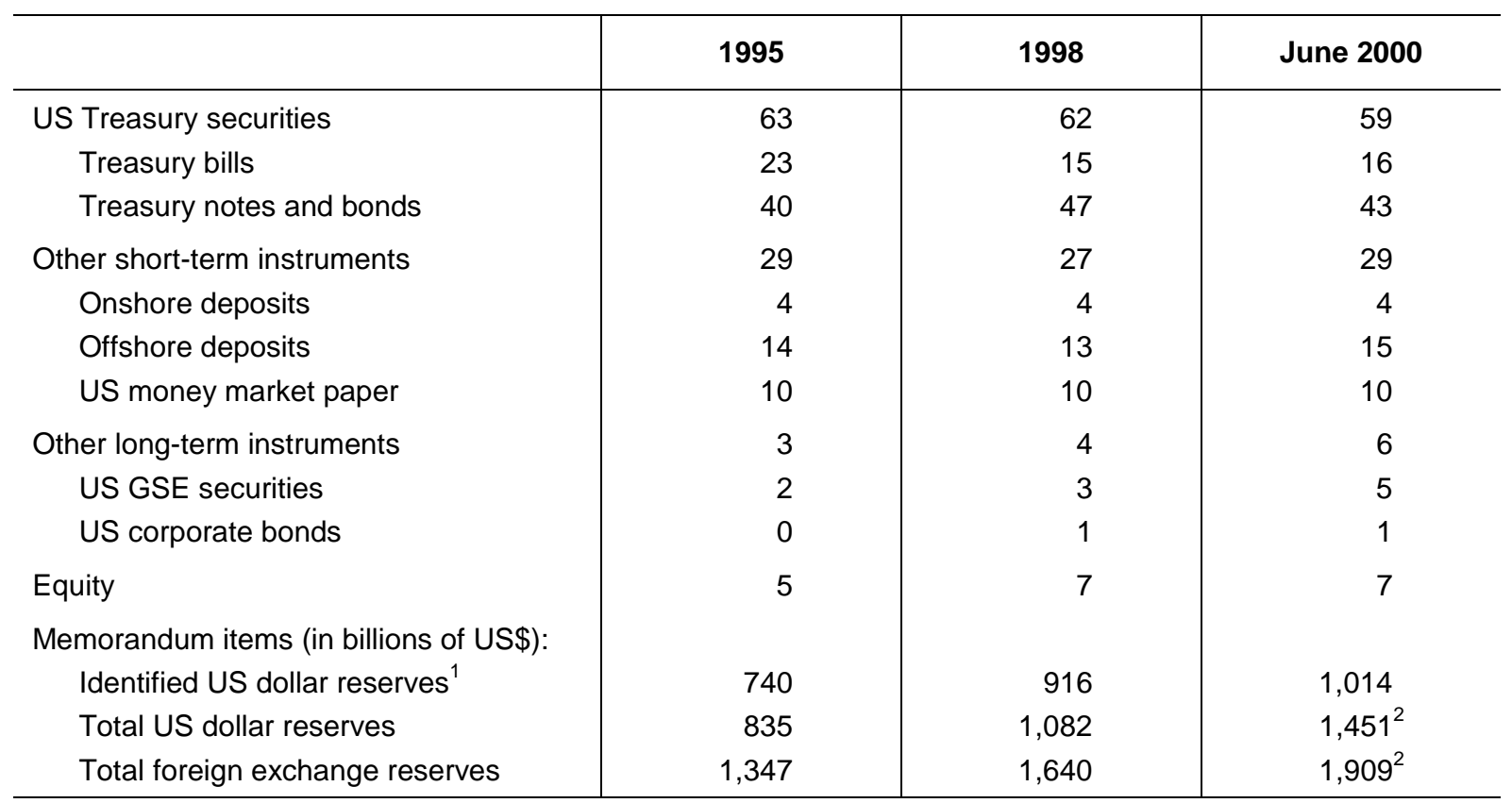

${ }^{1}$ Identified US dollar reserves exclude US dollar-denominated securities held outside the United States, such as international dollar bonds. ${ }^{2}$ December 2000.

Sources: Fung and McCauley (2000); US Treasury; BIS calculations. 
Another external operational issue is foreign exchange intervention. Market commentary suggests that since the mid-1990s, central banks have increasingly used electronic brokers to intervene in the major foreign exchange markets. The growing role of electronic trading in foreign exchange markets presents several strategic questions for intervening central banks. On the one hand, the transparency of prices in a screen-based currency dealing system may make it increasingly difficult for central banks to intervene in secret. On the other hand, central banks may find electronic broking systems a good tool to use when they need to be seen to be intervening.

\section{References}

Allen, $\mathrm{H}$ and J Hawkins (2002): "Electronic trading in wholesale financial markets: its wider impact and policy issues", Bank of England Quarterly Bulletin, Spring, pp 50-58.

Allen, H, J Hawkins and S Sato (2001): "Electronic trading and its implications for financial systems", Electronic finance: a new perspective and challenges, BIS Papers, no 7, Basel, November, pp 30-52.

Bank for International Settlements (1995): "Financial structure and the monetary policy transmission mechanism", CB 394, Basel, March.

(1999): 69th Annual Report, Basel, June.

(2000): "Overview of global financial developments: markets turn cautiously optimistic", BIS Quarterly Review, August, pp 1-12. pp 1-12.

(2001a): "Overview: the recovery keeps investors waiting", BIS Quarterly Review, September,

(2001b): "The changing shape of fixed income markets," The changing shape of fixed income markets: a collection of studies by central bank economists, BIS Papers, no 5, Basel, October, pp 1-43.

(2002): Triennial central bank survey of foreign exchange and derivatives market activity in 2001, Basel, March.

Barth, M J and V A Ramey (2001): "The cost channel of monetary transmission", NBER Macroeconomics Annual 2001, vol 16, eds B Bernanke and K Rogoff, MIT Press, forthcoming.

Bernard, H and S Gerlach (1996): "Does the term structure predict recessions? The international evidence", BIS Working Papers, no 37, September.

Bond Market Association (2001): eCommerce in the fixed income markets: the 2001 review of electronic transaction systems, Washington DC, December.

Borio, C E V (1997): "The implementation of monetary policy in industrial countries: a survey," BIS Economic Paper, no 47, July.

(2000): "Market liquidity and stress: selected issues and policy implications," BIS Quarterly Review, November, pp 38-51.

(2001): "A hundred ways to skin a cat: comparing monetary policy operating procedures in the United States, Japan and the euro area", Comparing monetary policy operating procedures across the United States, Japan and the euro area, BIS Papers, no 9, Basel, December, pp 1-22.

Borio, C E V and R McCauley (1996): "The economics of recent bond yield volatility", BIS Economic Papers, no 45, July.

Borio, C E V, C Furfine and P Lowe (2001): "Procyclicality of the financial system and financial stability: issues and policy options", Marrying the macro- and micro-prudential dimensions of financial stability, BIS Papers, no 1, March, pp 1-57.

Breedon, F (2001): "Market liquidity under stress: observations from the FX market," Market liquidity: proceedings of a workshop held at the BIS, BIS Papers, no 2, April, Basel, pp. 149-51.

Claessens, S, T Glaessner and D Klingebiel (2001): "E-finance in emerging markets: is leapfrogging possible?", World Bank Financial Sector Discussion Paper, no 7, June. 
Cohen, B (2000): "Credit spreads and equity market volatility", BIS Quarterly Review, November, pp 10-13.

Committee on the Global Financial System (1999a): Market liquidity: research findings and selected policy implications, CGFS Report, no 11, Basel, BIS, May.

October.

(1999b): A review of financial market events in autumn 1998, CGFS Report, no 12, Basel, BIS,

(1999c): CGFS issues recommendations for the design of liquid markets, CGFS Report, no 13, Basel, BIS, October.

(2000): Stress testing by large financial institutions: current practice and aggregation, CGFS Report, no 14, Basel, BIS, April.

BIS, January.

(2001a): The implications of electronic trading in financial markets, CGFS Report, no 16, Basel, (2001b): "Structural aspects of market liquidity from a financial stability perspective", CGFS Discussion Note, no 1, Basel, BIS, June.

(2001c): Collateral in wholesale financial markets: recent trends, risk management and market dynamics, CGFS Report, no 17, Basel, BIS, March.

(2001d): A survey of stress tests and current practice at major financial institutions, CGFS Report, no 18, Basel, BIS, April.

Counterparty Risk Management Policy Group (1999): Improving Counterparty Risk Management Practices, June.

Crockett, A (2000): "Marrying the micro- and macro-prudential dimensions of stability", BIS Speeches, remarks before the 11th International Conference of Banking Supervisors, 21 September.

- (2001): "Financial market distress: causes, consequences and policy options", BIS Speeches, remarks before the 26th Annual Meeting of IOSCO, 27 June.

Danielsson, J, H S Shin and J-P Zigrand (2001): "Asset price dynamics with value-at-risk constrained traders", presented at the Future of Bank Capital Standards Conference in Amsterdam, 18 June.

Dufour, A and R F Engle (2000): "Time and price impact of a trade", Journal of Finance, vol 55, no 6, December, pp 2467-98.

Estrella, A and F Mishkin (1998): "Predicting US recessions: financial variables as leading indicators," Review of Economics and Statistics, pp 45-61.

Euro-currency Standing Committee (1994): Macroeconomic and monetary policy issues raised by the growth of derivatives markets, CGFS Reports, no 4, Basel, BIS, November.

European Central Bank (2001a): The euro money market, Frankfurt, July.

(2001b): The euro bond market, Frankfurt, July.

(2001c): The euro equity markets, Frankfurt, August.

Fair, R C (2001): "Events that shook the market," Market liquidity: proceedings of a workshop held at the BIS, BIS Papers, no 2, April, Basel, pp 8-24.

Fender, I (2000a): "Corporate hedging: the impact of financial derivatives on the broad credit channel of monetary policy", BIS Working Papers, no 94, November.

(2000b): "The impact of corporate risk management on monetary policy transmission: some empirical evidence", BIS Working Papers, no 95, November.

Fleming, M (2001): "Measuring treasury market liquidity," Federal Reserve Bank of New York Staff Reports, no 133, July.

Fleming, M and E M Remolona (1999a): "What moves bond prices?" Journal of Portfolio Management, Summer, pp 28-38.

(1999b): "Price formation and liquidity in the US Treasury market: the response to public information," Journal of Finance, vol 54, pp 1901-16. 
Furfine, C (2001): "Do macro announcements still drive the US bond market?" BIS Quarterly Review, June, pp 49-57.

Furfine, C and E M Remolona (2002): "Price discovery in a market under stress: the U.S. Treasury market in fall 1998", BIS Working Papers, Basel, forthcoming.

Fung, B and R N McCauley (2000): "Composition of US dollar foreign exchange reserves by instrument", BIS Quarterly Review, November, pp 59-60.

Galati, G (2000): "Forex trading volumes, volatility and spreads in emerging market countries", BIS Quarterly Review, November, pp 49-51.

(2001): "Why has global FX turnover declined? Explaining the 2001 triennial survey", BIS Quarterly Review, December, pp 39-47.

Galati, G and K Tsatsaronis (2001): "The impact of the euro on Europe's financial markets," BIS Working Papers, no 100, July.

Gennotte, G and H Leland (1990): "Market liquidity, hedging and crashes", American Economic Review, December, pp 999-1021.

Gertler, M and C S Lown (2000): "The information in the high yield bond spread for the business cycle: evidence and some implications", NBER Working Paper, no 7549.

Group of Ten (G10) finance ministry and central bank deputies (2001): Consolidation in the financial sector, BIS, Basel, January.

Hanson, M S (2000): "The 'price puzzle' reconsidered", Wesleyan University Working Paper, September.

Harris, L (1990): "Liquidity, trading rules and electronic trading systems," Monograph Series in Finance and Economics, no 4, Stern School of Business, New York University.

Hattori, M, K Koyama and T Yonetani (2001): "Analysis of credit spread in Japan's corporate bond market", The changing shape of fixed income markets: a collection of studies by central bank economists, BIS Papers, no 5, Basel, October, pp 113-46.

Hawkins, J and D Mihaljek (2001): "The banking industry in the emerging market economies: competition, consolidation and systemic stability: an overview", The banking industry in the emerging market economies: competition, consolidation and systemic stability, BIS Papers, no 4, August, pp 1-44.

Investment Company Institute (2001): Mutual fund fact book, Washington DC, ICI, May.

Lown, C, D P Morgan and S Rohatgi (2000): "Listening to loan officers: the impact of commercial credit standards on lending and output," Federal Reserve Bank of New York Economic Policy Review, vol 6, no 2, July, pp 1-16.

Lyons, R (2001): The Microstructure Approach to Exchange Rates, MIT Press, Cambridge, MA.

Madhavan, A (2000): "Market microstructure: a survey", Journal of Financial Markets, vol 3, pp 205-58.

Marumo, K, T Nakayama, S Nishioka and T Yoshida (2002): "Impact of the new Bank of Japan monetary policy framework on bond markets", Bank of Japan Working Paper, forthcoming.

McCauley, R N (2001): "Benchmark tipping in the money and bond markets", BIS Quarterly Review, March, pp 39-45.

McCauley, R N and E M Remolona (2000): "Size and liquidity of government bond markets," BIS Quarterly Review, November, pp 52-60.

Morris, S and H S Shin (2000): "Market risk with interdependent choice", Liquidity Risk: Rethinking Risk Management, Centre for Financial Studies, 30 June /1 July.

Muranaga, J and T Shimizu (1999): "Market microstructure and market liquidity," Market liquidity: research findings and selected policy implications, CGFS Report, no 11, Basel, BIS, May.

OECD (1989): Systemic Risks in Securities Markets, Paris, Organisation for Economic Co-operation and Development.

O’Hara, M (1995): Market Microstructure Theory, Cambridge MA, Blackwell. 
(2001): "Overview: market structure issues in market liquidity," Market liquidity: proceedings of a workshop held at the BIS, BIS Papers, no 2, April, Basel, pp 1-8.

Rule, D (2001): "The credit derivatives market: its development and possible implications for financial stability", Bank of England Financial Stability Review, no 10, June, pp 117-40.

Rutter, J, K Macbeath and A Totten (2002): "Foreign exchange survey: currency's new clout", Global Investor, March, pp 46-55.

Schinasi, G J, C F Kramer and T Smith (2001): Financial implications of the shrinking supply of US Treasury securities, International Monetary Fund, March.

Swaps Monitor (2000): "Effects of Chase Manhattan-JP Morgan merger", mimeograph.

Tsatsaronis, K (2000a): "Hedge funds”, BIS Quarterly Review, November, pp 61-71. pp 12-13.

(2000b): "An indicator of investors' attitude towards risk", BIS Quarterly Review, February,

- (2001): "Market practice ahead of institutional structures in pricing euro area securities: country versus sector effects", BIS Quarterly Review, March, pp 13-14.

Upper, C (2001): "How safe was the 'safe haven'? Financial market liquidity during the 1998 turbulences," Market liquidity: proceedings of a workshop held at the BIS, BIS Papers, no 2, April, Basel, pp 241-66.

Wojnilower, A M (2000): "Life without treasury securities," Business Economics, October, pp 10-15.

Wooldridge, P D (2001): "The emergence of new benchmark yield curves", BIS Quarterly Review, December, pp 48-57. 